\title{
STEM Education through the Perspectives of Secondary Schools Teachers and School Administrators in Turkey
}

\author{
Mustafa ÇEVİK ${ }^{1}$ \\ Esma ÖZGÜNAY ${ }^{2}$
}

'Department of Primary Education, Karamanoğ lu Mehmetbey University, Karaman, Turkey Email:mustafacevik@kmu.edu.tr.Tel:+905062241885

${ }^{2}$ Ministry of National Education, Karaman/Turkey, Turkey

Email:ozgunayesma@gmail.com Tel:+905079427775

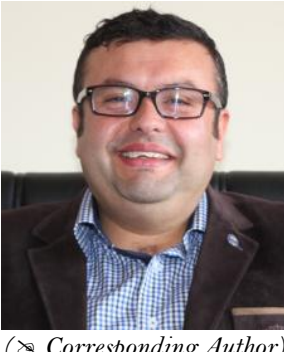

\begin{abstract}
The aim of this study is to explore the views of science, mathematics and information technologies teachers working in secondary schools and administrators of the schools, in which these teachers are working, regarding STEM. This research is based on a survey model in which quantitative data tools were used to directly obtain the opinions of teachers about STEM education; in parallel qualitative data tools were used to deeply understand the views of administrators about STEM education. The sample of the study consisted of 136 STEM field educators working in 21 state and private public secondary schools and 45 administrators working in these schools. While views of teachers indicated that the impact of STEM on students was higher than its effect on courses and teachers with each subscale of the quantitative data collection tool conducted with teachers, no significant relation was observed between these findings, gender and branch variables. Similarly, administrators stated that STEM is more effective on the students, teachers are not well equipped to teach STEM, they need to train themselves to implement STEM in courses and curriculums should be prepared on a STEM basis.
\end{abstract}

Keywords: STEM perspective, STEM secondary school education, Views of administrators about STEM, Views of teachers about STEM JEL Classification: STEM education, STEM perspective, Secondary school, Teachers, Administrators.

Citation | Mustafa ÇEVIK; Esma ÖZGÜNAY (2018). STEM Education through the Perspectives of Secondary Schools Teachers and School Administrators in Turkey. Asian Journal of Education and Training, 4(2): 91-101.

History:

Received: 1 February 2018

Revised: 24 February 2018

Accepted: 28 Febry 2018

Published: 5 March 2018

Licensed: This work is licensed under a Creative Commons

Attribution 3.0 License (cc) $\mathrm{Er}$

Publisher:Asian Online Journal Publishing Group
Contribution/Acknowledgement: All authors contributed to the conception and design of the study.

Funding: This study received no specific financial support

Competing Interests: The authors declare that they have no conflict of interests.

Transparency: The authors confirm that the manuscript is an honest, accurate, and transparent account of the study was reported; that no vital features of the study have been omitted; and that any discrepancies from the features of the study have been omit
study as planned have been explained.

Ethical: This study follows all ethical practices during writing.

\section{Contents}

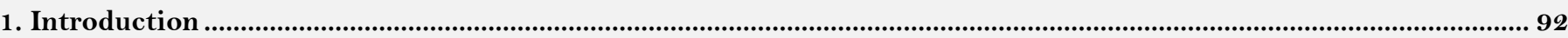

2. Methodology

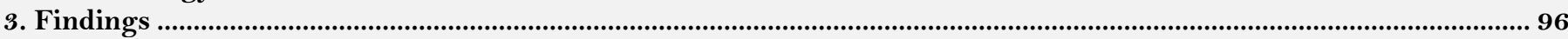

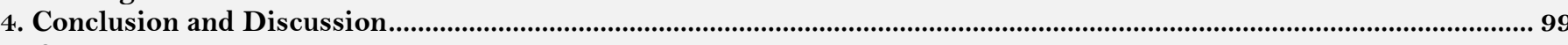

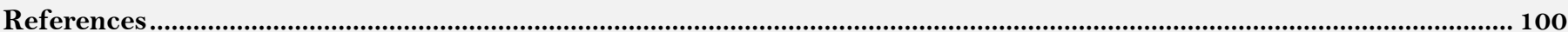




\section{Introduction}

Countries aim to adapt to rapidly evolving and chancing information and technology as well as advance their competition with each other through intellectual power rather than physical force in this digital age. The only way to achieve all this harmony and success is through education. In this regard, it is inevitable that the achievements gained through individual disciplines to educate individuals who think innovatively and produce creative solutions for the new problems, which is the main aim of the education, are insufficient. The new educational trend of the new world is the introduction of new outcomes through multidisciplinary studies. STEM (Science, Technology, Engineering, Mathematics) education is at the forefront of interdisciplinary approaches in education. STEM stands for Science, Technology, Engineering, Mathematics and it is a new educational approach focusing on teaching of design-centered knowledge and skills of these areas. The STEM education is vital in terms of its purposes such as taking big steps in the industrialization of the countries, having the promise of the global market, providing economic advantage as well as educating qualified individuals who are component in the current and future generations of business. For this reason, given the necessary importance to STEM education, the education of STEM literate students from kindergarten to university, the employment of these pupils according to their individual qualifications in industry and industrial areas should be among the important targets in terms of industrial and economic development of countries.

It is indisputable that individuals with qualified manpower are required to have scientific competences in mathematics and science in the age where information and technology change rapidly every second. However as long as these scientific competences do not integrate with the applicability of technology and engineering, they will not be able to respond people's future expectations and problems. The aim of STEM education, which consists of science and mathematics, the source of scientific data, as well as technology and engineering disciplines that are their application areas, is to integrate these four disciplines in order to improve students' problem solving abilities with a holistic and positive perspective, enable them to explore their creativity to obtain products. Ensuring the students to acquire aforementioned STEM gains is only possible through trained educators equipped with the necessary skills.

Teacher competencies proposed by Turkey Ministry of National Education include knowledge, skills and attitudes that ought to be gained by teachers who accomplish the curriculums developed for effective teaching and learning and prepare students for the 21 st century (MNE, 2017). According to these competencies, teachers of 21 st century are expected to have high-level of thinking skills, become digital literate, ensure students to develop their creativity by providing opportunities for material preparation and development as well as apply scientific research methods and techniques. In short, it can be said that the Turkish National Education System desires teachers with STEM competencies. However, the studies about STEM education into teachers, which is already carried out in Turkey, are still in the beginning stage comparing the studies in developed countries. In addition, the necessity for the people who developed themselves in STEM professions in recent years around the world revealed the need for STEM education (Öner and Capraro, 2016). It is obvious that STEM awareness is insufficient especially for students, teacher candidates, teachers and administrators in Turkey (Çevik et al., 2017). Therefore, it is observed that teachers who graduated from the universities and teacher candidates in Turkey do not graduate with sufficient training and their in-service training is not complementary for the deficiencies of the teachers regarding STEM education. It was reported that especially secondary school science teachers both in Turkey and some other countries feel incompetent regarding STEM education and university-industry collaboration is required to achieve these qualifications (El-Deghaidy et al., 2017). Similarly, it was stated that school administrators should be more involved within STEM education in the implementation of STEM programs in schools and they should be able to improve themselves in this regard (Al Salami et al., 2017).

In order to integrate the holistic interdisciplinary approach provided by the STEM education into the education system in Turkey, it is necessary to ensure awereness of teacher candidates when they enrolled in the education faculty, improve their consciousness and sentience and increase awareness of existing teachers through support training programs and in-service training. In this context, educating future STEM teachers can be facilitated by focusing on the development of teacher training undergraduate programs (Erdoğan and Çiftçi, 2017). Furthermore, teachers' realization of STEM education in the classroom help them gain self-confidence regarding STEM (Çetin and Balta, 2017). Positive attitudes \& views towards STEM are very important in order for such initiatives to contribute into the professional developments of the teachers and teacher candidates (Laboy-Rush, 2011). To enhance students' perceptions and interests in STEM, teachers need to develop positive attitudes toward teaching beyond their disciplines, positive attitudes toward collaboration with other teachers, and willingness to change current instructional strategies (Al Salami et al., 2017). Guskey (2002) visualized the change emerged in teachers' beliefs and attitudes after their professional development and teaching experiences as follows:

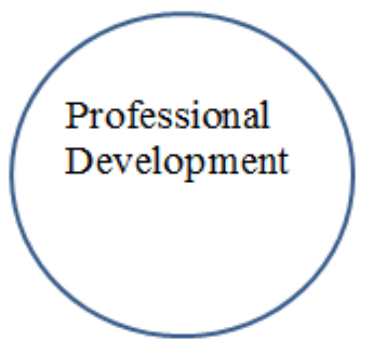

Source: Guskey (2002)

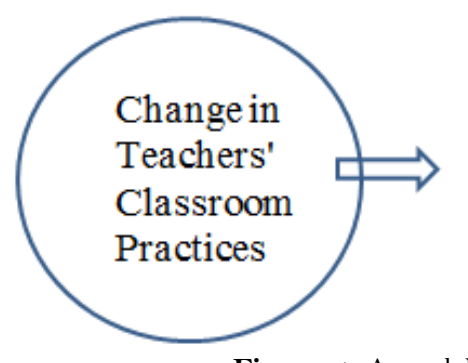

Figure-1. A model of teacher change

Student

Learning

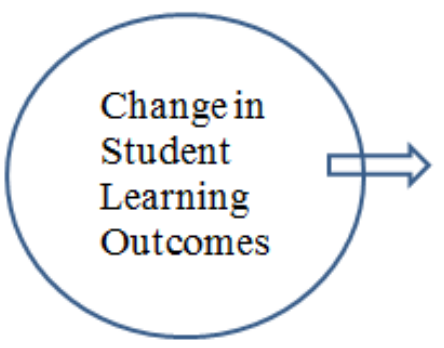

Outcomes

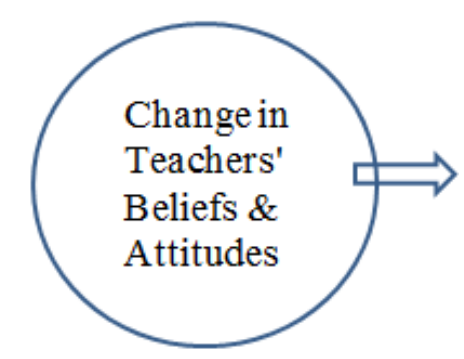

Beliefs \&

Attitudes

Significant changes in teachers 'attitudes and beliefs begin to emerge after they first observe evidence of improvement in students' learning. These improvements usually result from changes in teachers' classroom practices - from a new teaching approach, the use of new materials, the use of curricula, or a change in class format (Guskey, 2002). From this point of view, it can be said that the attitudes and beliefs that affect teachers' views 
towards STEM depend on teaching methods and techniques implemented in their classes. The methods, techniques or strategies to be used are directly related to the professional development of the teachers. In this context, it is important to identify the awareness of teachers who are the practitioners of STEM education and school administrators about STEM education in order to illuminate numerous points. The presence of teachers and school administrators with high professional development in the STEM field in secondary schools, which is one of the most important of the educational stages, means that students actively engage and improve themselves in STEM activities.

\subsection{Literature Review and Purpose of Study}

Spanneut (2010) argued that teachers would want to take risks in various learning opportunities when they are less stressed as a matter of course and they believe they can trust their managers. In reality, teachers give support more each other by sharing information among each other and willing to cooperate by helping each other when they feel confident towards their colleagues. This situation is more preliminary for STEM field teachers and very important in terms of functionality. Oparaocha (2017) carried out a case study in his doctoral dissertation with the managers and teachers of STEM schools that indicated high and low performance in the city center. At the end of the study, he lined up items that affected the STEM performance of the school. Within these, he pointed out the idea that an effective STEM education can be realized in the school in which an efficient manager with high STEM awareness cooperate with his colleagues. Pinnell et al. (2013) aimed to improve the knowledge and skills of teachers and teacher candidates about STEM education and prepared 6-week program designed to increase teachers' engineering and design knowledge, in which 10 teachers and 5 teacher candidates participated. Participants were involved in workshops and activities related to curriculum development, inquiry-based learning and conceptual framework of STEM education. They then worked with an engineer candidate studying at the engineering faculty, a lecturer from the engineering faculty and an engineer working in the industry. Researchers evaluating program outputs indicated that participating teachers developed their STEM skills and continued to develop their skills by leading the implementation of STEM education in their schools.

In the study of Alumbaugh (2015) in which the data collected through qualitative means, three leaders from a professional STEM company, four primary school principals, and six primary school teachers participated in Missouri. It was identified that each of the leaders of the STEM professional companies has positive attitudes towards STEM for STEM education and each leader strongly stands for STEM education at the primary education stage. The perceptions of school principals and teachers are similar. Both the principal and the teachers stated that STEM education has the potential to improve participation of the students and increase their achievements. Tamara et al. (2016) identified that teachers were primary factors affecting students' STEM career plans at the primary education stage. The views of teachers for STEM are crucial as they have an important position that affects the future of the students. Kristin et al. (2016) conducted a study with science, mathematics and education faculty coordinators, secondary school administrators, teachers and students in order to introduce and describe a professional development model. The study is a practice with the design difficulties in STEM theme during summer term. Teachers, students, administrators and other participants collaborated together within this practice. At the end of the study, the teachers gave opinions on 2 important topics related to STEM designs. The first of these is practices and motivations of students in science, mathematics and engineering fields and the second is participation in the activity and the form of embracing the activity. These opinions, which also indicate the basic principles of STEM education, are an important aspect in making the students active in STEM activities. At the same time this study also identified resistances to traditional structures of the curriculum and schools. Based on these findings, a course of action was identified for more effective STEM education. Çınar et al. (2016) pointed out in their STEM-focused studies conducted with science teacher candidates that participants only associate natural sciences with mathematics before participating STEM training and they consider involving technology and engineering as well in teaching natural sciences after STEM training. Çetin and Balta (2017) strongly recommended that teachers should be trained for STEM practices, and this should be carried out with the inservice training. In this way, teacher will be able to realize their class activities more easily by gaining experiences in the STEM education.

\subsection{Rationale of the Study}

When examining the literature, it is revealed that teacher candidates and teachers should be equipped in this regard as well as their professional developments are important in order to achieve the certain objectives of the STEM education. Furthermore, secondary school teachers are expected to have high levels of STEM awareness, interests and attitudes. Teachers who will train individuals who are expected to reveal multidisciplinary solutions to the multidisciplinary problems of the future should be able to plan STEM education process and the program properly and prepare the necessary materials and educational environments. Researches indicate that the interest in STEM subjects begins at the primary school and therefore the preparation of primary school teachers with STEM teaching competences is vital (DeBiase, 2016). Teachers should not be left alone in this process. School administrators should support the process in terms of teacher trainings, physical infrastructure, material design, setting of class hours, time management, informing families about the process and become the indirect enforcer of STEM education. According to DeBiase (2016) strong and positive relationships between managers, participants and teachers provide strong contributions to the success of the acquisition and integration of STEM content, curriculum and pedagogy.

Studies are limited examining STEM awareness of secondary school teachers and administrators in STEM fields in the national literature. In this regard, it is considered that the contribution of the study to the literature would be great. This study focuses on the views of teachers and school administrators about STEM education playing a key role in the spread of STEM education. For this purpose, it is aimed to evaluate the views of STEM field teachers and administrators in secondary schools related to STEM education, which has emerged as a new teaching approach in education in Turkey in recent years. The following questions were sought in this direction. 
1. What are the general views of STEM field teachers (Science, Mathematics, Information Technologies and Technology Design) working in secondary schools about the effect of STEM education on the students as well as the courses and the teachers?

2. Is there a significant correlation between genders of secondary school STEM field teachers and their views about STEM?

3. Is there a significant correlation between the branch variable and views of secondary school STEM field teachers about STEM?

4. What are the views of secondary school administrators about the effect of STEM education on the students, the courses and the teachers?

\section{Methodology}

This section describes the way in which the research was conducted, research methods that were used as well as the ways and techniques followed in identifying the views of school administrators and teachers participating in the study.

\subsection{Research Design}

The first part of the study was structured in a survey model based on quantitative research design. Survey models are research approaches that aim to describe the past or the present, as it exists. The case, the individual or the object that is the subject of the investigation is tried to be described as in their own circumstances and as are (Karasar, 2007).

Taking the views of school administrators constituting the second part of the research was carried out with the case study from qualitative research designs. A case study is a thorough investigation of a current phenomenon in a holistic approach under real circumstances (Baxter and Jack, 2008; Yin, 2009). Qualitative research aims to identify phenomena and cases in the authentic framework and tries to realize the truth about the situation rather than the generalization of research findings (Ekiz, 2004; Yıldırım and Şimşek, 2005). Research models used in the study support each other and tried to be used as efficiently as possible.

Study Group. While the participant group of this study was being constituted, the convenient sampling method was adopted from non-random sampling methods. This method ensures that certain conditions are present (Büyüköztürk et al., 2012). The participant group of the study consisted of administrators and STEM field teachers working at 21 secondary schools in Karaman. A total of 45 school administrators who are principals or deputy principals and 136 STEM teachers including science, mathematics and information technologies working in these schools participated on a volunteer basis. The demographic characteristics of the teachers and administrators involved in the research are detailed below. Table 1 indicates the demographic information of the teachers participated in the research.

Table-1. Demographic Characteristics of Participant

\begin{tabular}{l|l|l|l}
\hline Independent Variable & Groups & f(frequency) & \% (percentage) \\
\hline \multirow{2}{*}{ Gender } & Female & 59 & 43.4 \\
& Male & 77 & 56.6 \\
\hline \multirow{3}{*}{ Branch } & Science & 55 & 40.4 \\
\cline { 2 - 4 } & Mathematics & 53 & 39 \\
\cline { 2 - 4 } & Information Technologies & 28 & 20.6 \\
\hline TOTAL & & 136 & 100 \\
\hline
\end{tabular}

As seen in Table 1, of the teachers participated in the research, $59(43.4 \%)$ were female, 77 (56.6\%) were male. In addition, $55(40.4 \%)$ were science teachers, 53 (39\%) were mathematics teachers and 28 (20.6\%) were information technologies teachers. The demographic features of school administrators participating in the study are shown in Table 2.

Table-2. Demographic Characteristics of Administrators participating in the Study

\begin{tabular}{|c|c|c|c|}
\hline Independent Variable & Groups & $f$ & $\%$ \\
\hline \multirow[b]{2}{*}{ Gender } & Female & 8 & 17.8 \\
\hline & Male & 37 & 82.2 \\
\hline \multirow{2}{*}{ Title } & Manager & 20 & 44.4 \\
\hline & Deputy Manager & 25 & 55.6 \\
\hline \multirow{5}{*}{ Term of Office } & $1-5$ & 24 & 53.3 \\
\hline & $6-10$ & 9 & 20 \\
\hline & $11-15$ & 8 & 17.7 \\
\hline & $15-20$ & 2 & 4.5 \\
\hline & 21 and over & 2 & 4.5 \\
\hline \multirow{4}{*}{ Graduation } & Education & 32 & 71.1 \\
\hline & Science/Literature & 6 & 13.3 \\
\hline & Theology & 4 & 8.9 \\
\hline & Vocational Education & 3 & 6.7 \\
\hline TOTAL & & 45 & 100 \\
\hline
\end{tabular}

Of the school administrators participated in the study, 8 (17.8\%) were female, 37 (82.2\%) were male. In addition, $20(44.4 \%)$ were principals, $25(55.6 \%)$ were deputy principals. Of the school administrators participated in the research, $24(53.3 \%)$ had $1-5$ years, 9 (20\%) had 6-10 years, $8(17.7 \%)$ had $11-15$ years, 2 (4.5\%) had $15-20$ years and $2(4.5 \%)$ had 21 years and over of professional experience. The school administrators involved in the 
study were all in secondary schools. Of the school administrators participating in the study, 32 (71.1\%) graduated from the education faculty, $6(13.3 \%)$ graduated from the faculty of science and literature, 4 ( $8.9 \%)$ graduated from the faculty of theology and $3(6.7 \%)$ graduated from the faculty of vocational education.

\subsection{Design and Implementation of Data Collection Instruments}

Survey Preparation and Implementation Procedure. Views about the same topic from two different sample groups were collected by two different methods in the research. The 5-point Likert-type questionnaire named "Views of Secondary School Teachers about STEM", one of the quantitative data collection tools, that aims to collect data from STEM field teachers, which is the first study group, consists of 2 sections. The first part of the questionnaire is "Views about the Effects of STEM on Students" and the second part is "Views about the Effects of STEM on Courses and Teachers". Survey questions were developed by the researchers and interviews had been held with 20 teachers within different platforms in order to explore readiness level of teachers for STEM before the items were prepared and the answers were recorded, evaluated and eventually items were prepared in this direction. Validity reliability studies of the 24-item questionnaire were performed.

Validity and Reliability Studies of the Questionnaire. The questionnaire was finalized by the examination of a specialist in measurement field, a specialist in mathematics education, two academicians specializing in science education and a science and classroom teacher. An item was removed as it was not adequate for the study and three items were amended and finalized, as they were not clear in line with the opinions of experts. The questionnaire in which the content validity was provided in the direction of expert opinions was employed to 136 teachers. The explanatory factor analysis was performed for the construct validity of the questionnaire. The KMO value is .84 and the factor analysis was performed since this value was higher than the minimum value of .60 required to perform the factor analysis indicated in the literature (Pallant, 2007). The value of Barlett's test of sphericity was significant at $\left(\mathrm{X}^{2}(105)=878.605 ; \mathrm{p}<.01\right.$ level. In other words, the study group to which the questionnaire was applied can represent the population. When the factor analysis is carried out, the items that have a factor load value of .45 and above are strictly considered to be included in the scale (Kline, 2000; Büyüköztürk, 2009). Therefore Items 8, 9, 10, 11, 15, 17, 18, 20 and 22 were not included in the survey. 25-degree "varimax" axis rotation was performed during factor analysis. According to analysis results, the items for which construction validity was carried out were included in the final scale. The scale consists of two sub-dimensions and 15 items. While the first sub-dimension of the scale, item $1,2,3,4,5,6$ and 7 , measures the effect of STEM on students, item $12,13,14,16,19,21,23$ and 24 measure the effect of STEM on courses and teachers. The factor loading values of items assessing views about the effect of STEM on students range from .58 to .78. The sub-dimension consisted of 7 items. The factor loading values of items assessing views about the effect of STEM on courses and teachers range from .49 to .79. This sub-dimension consisted of 8 items. These two factors appeared to explain $52 \%$ of the total variance. It is stated in the literature that it is sufficient to have a range of $40 \%$ to $60 \%$ of the variance explained in multiple-factor measurement instruments (Tavşancil, 2005). In this regard, the variance of the two sub-dimensions is sufficient for the survey as is in the original survey. Internal consistency coefficient was examined with Cronbach alpha for the reliability of the questionnaire. This coefficient was calculated as .87 for the survey. For the sub-dimensions, it was calculated as .87 for the subscale of student-directed effect and it was calculated as .82 for the subscale of courses and teachers-directed effect. It is well known in the literature that the value of .70 or over is sufficient for the reliability (Field, 2005).

Interview Form Preparation and Implementation Procedure. The semi-structured interview form, one of the qualitative data collection tools, was used to obtain in-depth data from school administrators, which is the second study group of the study. In this form prepared by the researchers principles such as easy to understand, preparing focused questions, avoiding asking multi-dimensional questions, asking open-ended questions, avoiding steering, preparing alternative questions and probes, writing different sorts of questions and organizing questions in a logical way were considered (Yıldırım and Şimşek, 2005). It was noted that the questions in the form were parallel to the questions posed to teachers who were in the first study group. In this regard, the form consisted of two parts and questions emerged in the light of four themes. The first part of the form is the "demographic part" and the second part is the "views about STEM part". The second part consisted of four main themes: "STEM perception”, “opinions about the contribution of STEM to students”, “opinions about the implementation of STEM in the course/school" "opinions about conducting STEM by teachers" and questions were prepared for four subthemes. Themes in the interview form and questions for sub-themes are shown in Table 3.

Table-3. Themes and Questions for Sub-themes in the Interview Form

\begin{tabular}{l|l}
\hline Theme and Sub-Themes & Questions \\
\hline $\begin{array}{l}\text { 1. Theme } \\
\text { STEM perception }\end{array}$ & 1 \\
\hline $\begin{array}{l}\text { 1.1. Sub-theme } \\
\text { How the perception obtained }\end{array}$ & 1.2 \\
\hline $\begin{array}{l}\text { 2. Theme } \\
\text { The contribution of STEM to students }\end{array}$ & 2 \\
\hline $\begin{array}{l}\text { 3. Theme } \\
\text { The feasibility of STEM education }\end{array}$ & 3 \\
\hline $\begin{array}{l}\text { 3.1. Sub-theme } \\
\text { Things to be done for STEM education }\end{array}$ & 3.1 \\
\hline $\begin{array}{l}\text { 3.2. Sub-theme } \\
\text { The reason for not fulfilling STEM education in the course }\end{array}$ & 3.2 \\
\hline $\begin{array}{l}\text { 4. Theme } \\
\text { Readiness of teachers for STEM education }\end{array}$ & 4 \\
\hline $\begin{array}{l}\text { 4.1. Sub-theme } \\
\text { What teachers need to do for STEM education }\end{array}$ & 4.1 \\
\hline $\begin{array}{l}\text { Source: From data collected } \\
\end{array}$
\end{tabular}


Validity and Reliability Studies of the Interview Form. The semi-structured interview form prepared by the researchers was evaluated by a specialist academician in the field of measurement, an academician in mathematics, science and classroom instruction and an expert in Turkish, science and classroom teachers in order to identify the content validity. The "STEM Executive Interview Form Check Mark" developed by the researchers was used to evaluate the questions. The experts indicated that questions are appropriate for their purposes in this form in which the questions were evaluated. It this direction, it can be said that the form has the validity feature.

After piloting with school administrators participating in the research, the answers given by the administrators for the open-ended questions were examined by both the researchers and a lecturer other than the researchers. The issues in which "consensus" and "disagreement" emerged were discussed in the scope of themes and sub-themes and amendments were provided in the interview form consisting of 8 questions. The reliability formula proposed by Miles and Huberman (1994) was used to calculate the reliability of the study. According to the method of Reliability $=$ Consensus / (Consensus + Disagreement), the reliability among the researchers was found as $.87=$ $(7 / 7+1)$. The similarity of the experts in coding is well. This indicates that the coding is reliable. According to Yıldırım and Şimşek (2005) it is assumed that the percentage of reliability was achieved when the agreement percentage is $70 \%$ in the reliability calculation. The interview form, in which validity and reliability was provided, was conducted with 45 school administrators face-to-face in the manager's office alone. Voice recording was offered but the participants did not opt for it. Participants were informed in written and verbally with the benefits and risks of participating in the study and they were explained that they could withdraw anytime they want and they would not be harmed in such a case.

\subsection{Data Analysis}

Qualitative Data Analysis. Prior to the analysis of the data, normality test was carried out to find out whether the data were normally distributed and it was found that the values of skewness and kurtosis are $\mathrm{p}<+1.5$ and $\mathrm{p}>$ 1.5 normal distribution. Both the skewness (-.43) and kurtosis (-.22) values of "Views about the Effect on Student" subscale and the skewness (-.02) and kurtois (-.27) values of the "Views about the Effect on Courses and Teacher" subscale are between $+1,5$ and $-1,5$. It is assumed that distribution is normal when the skewness and kurtosis values of the two subscales are between $+1,5$ and $-1,5$ (Tabachnick and Fidell, 2015). Therefore, the current study included independent t-test and one-way variance (ANOVA) analyzes that can be performed with normal distribution.

Qualitative Data Analysis. The "content analysis" technique considered in qualitative research paradigm was carried out to identify the opinions of school administrators about STEM, which is the second study group of the research. The content analysis is described as a systematic, repeatable technique in which some words on a text are summarized with smaller content categories with certain rules-based coding (Büyüköztürk et al., 2012). The content analysis requires an in-depth analysis of the data obtained and allows emerging previously unfamiliar themes and codes. The aim of such analysis is to present the findings to the reader in an organized and interpreted manner (Yıldırım and Şimşek, 2005). Prior the analysis, the themes and sub-themes were determined by the researchers taking into consideration the purpose of the study. Four main themes and answers given in the interview form consisting of four sub-themes were examined in detail. Similar data were grouped together with certain themes, interrelationships between data were structured, coded and frequency (f) and percentages (\%) were calculated and tabulated. Since the findings of the research should be presented within confidentiality boundaries (Mack et al., 2005; Dicicco-Bloom and Crabtree, 2006) participants were given numbers and their identities were kept confidential and the answers given the questions were only be used to provide the data for the investigation and quotations from raw data obtained from open-ended questions were presented (Patton, 2014).

\section{Findings}

In this section, findings and interpretations of the study were included within the objectives of the research.

\subsection{Findings Related to Opinions of Teachers about STEM Education}

The mean scores of teachers participating in the study about STEM in general, effect on students, effect on courses and teachers are given in Table 4.

Table-4. Descriptive Data on the Opinions of Teachers about STEM Education Scale and its Subscales

\begin{tabular}{l|l|l|l}
\hline Subscales & $\mathbf{N}$ & $\overline{\boldsymbol{X}}$ & Ss \\
\hline General views on STEM & 136 & 4.02 & .56 \\
\hline The Effect of STEM on the Students Subscale & 136 & 4.15 & .68 \\
\hline The Effect of STEM on the Courses and Teachers Subscale & 136 & 3.90 & .63 \\
\hline Source: From data collected &
\end{tabular}

As shown in Table 4 the mean score of the views of teachers participating in the study about STEM education is $\overline{\boldsymbol{X}}_{1}=4.02$. In other words, views of teachers about STEM is favourable in the positive direction. Similarly, the views of teachers about the effect of STEM on the students is $\overline{\boldsymbol{X}}_{2}=4.15$. The mean score of the views about the effect of STEM on the courses and teachers is $\overline{\boldsymbol{X}}_{3}=3.90$. It can be said that opinions about both subscales of the questionnaire are positive. However, it can also be said that teachers believe that the effects of STEM on the students are further $\left(\overline{\boldsymbol{X}}_{2}>\overline{\boldsymbol{X}}_{3}\right)$.

\subsection{Findings about Views of Teachers on STEM in Terms of Gender Variable}

Findings regarding the relationship between subscales of views about the effects of STEM on students,courses and teachers interms of the gender variable of teachers are shown Table 5. 
Table-5. t- Test for Sub-dimensions of the Scale by Gender Variable

\begin{tabular}{|c|c|c|c|c|c|c|c|}
\hline & Gender & $\mathbf{N}$ & $\overline{\bar{X}}$ & ss & $\mathbf{t}$ & sd & $\bar{p}$ \\
\hline \multirow{2}{*}{ The Effect of STEM on Students } & Female & 136 & 4.25 & .70 & \multirow[b]{2}{*}{1.44} & \multirow[b]{2}{*}{134} & \multirow{2}{*}{.15} \\
\hline & Male & 136 & 4.08 & .66 & & & \\
\hline \multirow[t]{2}{*}{ The Effect of STEM on Courses and Teachers } & Female & 136 & 3.95 & .67 & \multirow{2}{*}{.76} & \multirow{2}{*}{134} & \multirow{2}{*}{.44} \\
\hline & Male & 136 & 3.86 & .61 & & & \\
\hline
\end{tabular}

Source: From data collected

As seen in Table 5, there is no significant correlation between gender variable and the mean scores of the subscale of views about the effect of STEM on students. Similarly, there is no significant correlation between gender variable and the mean scores of the subscale of views about the effect of STEM on courses and teachers. From this point of view, it can be said that there is no relationship between gender of teachers and views that STEM has an impact on the students, courses and teachers. There is no difference according to gender.

\subsection{Findings Regarding Views of Teachers about STEM by Branch Variable}

Table-6. One-Way ANOVA regarding the Subscales of the Questionnaire by Branch Variable

\begin{tabular}{|c|c|c|c|c|c|c|}
\hline & Variance Source & Sum of Square & Sd & Mean Square & $f$ & $\mathrm{p}$ \\
\hline \multirow{3}{*}{ Effect of STEM on Students } & Between Groups & .75 & 2 & .37 & \multirow{3}{*}{.79} & \multirow{3}{*}{.45} \\
\hline & Within Groups & 62.61 & 133 & .47 & & \\
\hline & Total & 63.36 & 135 & & & \\
\hline \multirow[t]{3}{*}{ Effect of STEM on Courses and Teachers } & Between Groups & .60 & 2 & .30 & \multirow{3}{*}{.74} & \multirow{3}{*}{.47} \\
\hline & Within Groups & 54.46 & 133 & .41 & & \\
\hline & Total & 55.07 & 135 & & & \\
\hline
\end{tabular}

As seen in Table 6, there is no significant difference between the mean scores of views about the effect of STEM on the students by branch variable $(\mathrm{F}(2,133)=.79 ; \mathrm{p}>.05)$. In addition, it was observed that there is no significant difference between scores of views about the effect of STEM on courses and teachers, which is other subscale of the survey, by branch variable of the participants $(\mathrm{F}(2,133)=.74 ; \mathrm{p}>.05)$. That is to say, there is no significant correlation between braches of teachers and views that STEM education has an impact on both students as well as courses and teachers. There is no significant difference according to braches of the teachers.

\subsection{Findings Regarding Views of School Administrators about the Effect of STEM on the Students, Courses and Teachers}

Views of the school administrators participating the research about the effect of STEM education on the students, courses and teachers were presented by the content analysis method. The codes, percentages and frequencies of these views are given in Table 7 .

Table-7. Views of School Administrators about STEM

\begin{tabular}{|c|c|c|c|}
\hline Themes & Codes & $\mathrm{f}$ & $\%$ \\
\hline \multirow{3}{*}{ 1. STEM perception } & Available & 21 & 46.7 \\
\hline & Partially & 17 & 37.8 \\
\hline & Not Available & 7 & 15.5 \\
\hline \multicolumn{2}{|l|}{ Total } & 45 & 100 \\
\hline \multirow[t]{6}{*}{ 1.1. How the perception acquired } & Social environment & 8 & 38.1 \\
\hline & Congress/Conference/Competition & 6 & 28.6 \\
\hline & Internet & 3 & 14.2 \\
\hline & Own & 2 & 9.5 \\
\hline & Tv & 1 & 4.8 \\
\hline & Official Letter & 1 & 4.8 \\
\hline \multicolumn{2}{|l|}{ Total } & 21 & 100 \\
\hline \multirow[t]{7}{*}{ 2. The Effect of STEM on the Students } & Embodiment of information & 17 & 37.8 \\
\hline & Productivity & 8 & 17.8 \\
\hline & Contribution to cognitive, emotional and psychomotor skills & 4 & 8.9 \\
\hline & Curiosity/ Motivation & 5 & 11.1 \\
\hline & Expanding horizon & 2 & 4.4 \\
\hline & No contribution & 2 & 4.4 \\
\hline & No comment & 7 & 15.6 \\
\hline \multicolumn{2}{|l|}{ Total } & 45 & 100 \\
\hline \multirow{3}{*}{ 3. Implementation of STEM education } & Possible & 25 & 62.2 \\
\hline & Impossible & 15 & 26.7 \\
\hline & No comment & 5 & 11.1 \\
\hline \multicolumn{2}{|l|}{ Total } & 45 & 100 \\
\hline \multirow{4}{*}{ 3.1.Things to be done for STEM education } & Teacher Education & 11 & 44 \\
\hline & Practical courses & 8 & 32 \\
\hline & Curriculum should be developed & 5 & 20 \\
\hline & Physical infrastructure should be improved & 1 & 4 \\
\hline \multicolumn{2}{|l|}{ Total } & 25 & 100 \\
\hline \multirow[t]{3}{*}{ 3.2.The reason of not fulfilling STEM education } & Equipment inadequacy of teacher & 4 & 26.7 \\
\hline & Infrastructure inadequacy & 5 & 33.3 \\
\hline & Inappropriate for curriculum & 6 & 40 \\
\hline \multicolumn{2}{|l|}{ Total } & 15 & 100 \\
\hline \multirow[t]{2}{*}{ 4.Readiness of teachers for STEM } & Available & 2 & 4.4 \\
\hline & Not Available & 43 & 95.6 \\
\hline \multicolumn{2}{|l|}{ Total } & 45 & 100 \\
\hline \multirow[t]{4}{*}{ 4.1. What teachers need to do for STEM education } & In-service training & 27 & 60 \\
\hline & Self-training & 13 & 28.9 \\
\hline & STEM focused course planning & 1 & 2.2 \\
\hline & No comment & 4 & 8.9 \\
\hline \multicolumn{2}{|l|}{ Total } & 45 & 100 \\
\hline
\end{tabular}

Source: From data collected 
STEM Education Perception. Of the school administrators participating in the study, 21 (46.7\%) stated that they were informed of STEM education, $17(37.8 \%)$ were partially informed and $7(15.6 \%)$ did not have any information about the program.

How the STEM Education Perception were Acquired. Of the 45 administrators participating in the research, $8(38.1 \%)$ stated that they perceived the STEM education from the social environment, $6(28.5 \%)$ perceived from activities such as congresses / conferences / comptetitions, 3 (14.3\%) perceived from the internet, 2 $(9.5 \%)$ perceived by own investigating, $1(4.7 \%)$ perceived via TV and $1(4.7 \%)$ perceived through official letter.

Ms,DM24: "I perceived it from my social environment, from my friends" (8)

M5: "I perceived it from the conference / congress / competition I attended" (6)

$\boldsymbol{M g}, \boldsymbol{D M G}$ : "I perceived it from the internet" (3)

It is seen above that the school administrators who participated in the study perceived the STEM education from different streams. From the answers given, we can reach the conclusion that the STEM education in Turkey is becoming widespread on different platforms but the STEM education awareness is not fully realized.

Contribution of STEM Education to Students. Of the school administrators participating in the research, 17 $(37.8 \%)$ stated that STEM education would embody the information, $8(17.8 \%)$ stated that STEM education would make students productive, $5(11.1 \%)$ stated that it would provide curiosity and motivation, $4(8.9 \%)$ stated that it would contribute to the cognitive, emotional and psychomotor skills of the students, $2(4.4 \%)$ stated that it would expand the horizon of the students, $2(4.4 \%)$ stated that it would not provide any contribution and $7(15.6 \%)$ stated that they had no idea. In this regard, some excerpts from the school administrators participating in the study as follows:

M5: "It allows students to apply abstract theoretical information gained in schools to practice in real life." (2)

M15: "Allows students to realize their interests and talents." (2)

$2(4.4 \%)$ participants believe that STEM education does not have any contributions for the students. Participants expressed their views as follows:

M10: "There would be no contribution as long as it becomes permanent and a national system."

M14: "It cannot be effective if teachers would provide sufficient commitment."

Among participants, $7(15.6 \%)$ stated that they had no idea about what sort of benefits STEM education provides for students. It is seen above that secondary school administrators participating in the research have different opinions about the contribution of STEM education to students. From the answer given, $80 \%$ of principals have positive expectations about STEM education and $20 \%$ had some concerns arising from the fact that teachers are not self-sacrificing and the system is not permanent and national.

Implementation of STEM Education. While $25(62.2 \%)$ school administrators indicated that the implementation of STEM in the class is possible, $15(26.7 \%)$ indicated that this was not possible and $5(11.1 \%)$ stated that they did not have any ideas.

Things to be done to Implement STEM Education. Among school administrators participating in the research, $11(44 \%)$ stated that teacher training is required, $8(32 \%)$ said that it is necessary to shift to practical training, $5(20 \%)$ suggested that changes in the curriculum are required and $1(4 \%)$ stated that arrangements in the physical infrastructure of the school are required in order to implement STEM education. Some of the participants expressed their views on this topic as follows:

DM23: "Teachers should be given a serious in-service training, informed what to do and how to do it, equipped with a

new generation of information technologies." (2)

DM8: "Elective courses should be organized with STEM and hours of practice and workshops should be created." (1)

M2: "More time should be allocated for practice by reducing hours of theoretical lessons. Practice should be embraced chasing pattern information transfer ...." (1)

Various answers were received from the administrators participating in the research about things to be done to implement STEM education. It is seen that teachers are required to be equipped with in-service training for STEM education. In addition to teacher awareness, the administrators noted that arrangements need to be made in the curriculums, practical education should be included and the physical infrastructure of the school should be improved in order to implement STEM in courses.

Failure to Implement STEM Education in Courses. Among the administrators participating in the research, $6(40 \%)$ stated that curriculums are inadequate, $5(33.3 \%)$ reported that the infrastructure is insufficient and 4 $(26.7 \%)$ stated that the teachers have lack of equipment regarding STEM education due not to fulfill STEM education in classes. Some of the participants expressed their views on this issue as follows:

M7: "We do not have teachers equipped with STEM education to carry out activities."(1)

DM6: "There is a curriculum to catch up with and preparation for exams is not possible at all."(2)

From the answers above given by the administrators participating in the study, it is revealed that they are aware that STEM education is important for Turkey and for the education system, but lack of equipment of teachers, insufficient infrastructure, our examination system, intensity of the curriculum do not allow to apply STEM education in the courses.

Readiness of Teachers for STEM Education. Of the school administrators participating in the study, 43 $(95.6 \%)$ stated that teachers are not ready to teach STEM and $2(4.4 \%)$ stated that teachers are ready to teach STEM.

What Teachers Need to Do for STEM Education. Of the school administrators participating in the study, $27(60 \%)$ indicated that teachers needed in-service training, $13(28.9 \%)$ stated that teachers needed to train themselves, $4(8.9 \%)$ indicated that they had no ideas and $1(2.2 \%)$ noted that the preparation of STEM-focused curriculum is required.

As regards the topic, some of the participants expressed their views as follows:

Ms: "I believe that educators should be given training about the interaction of STEM education."(3)

MY14: "Teachers should acquire knowledge about not only their own fields but also about other fields, should plan their course plans according to STEM activities.” (1) 
MY 8: "Teachers should educate themselves firstly and participate effectively into in-service training, congress and conferences." (2)

\section{Conclusion and Discussion}

In this study, the opinions of secondary school teachers about STEM education were examined and evaluation of these opinions were carried out according to various variables. In addition, interviews were conducted with administrators in the secondary schools about STEM education and their opinions were examined in depth. When the literature examined, it seems that there are no qualitative and quantitative studies together about the opinions of both teachers and administrators regarding STEM education. The originality of the study is due to comparison and evaluation of the results obtained by interviewing the principals in parallel with the questions directed to the teachers. Thus, it made possible to evaluate and assess the views of the teachers and administrators, two important components of education, on STEM education as complementary data. As a result of the study, the mean score of the views of teachers about STEM obtained by the examination of the data collected quantitatively was observed as $\overline{\boldsymbol{X}}_{1}=4.02$. It can be said with this finding that opinions of teachers about STEM education are positive. This result is in accordance with many studies in the literature (Siew et al., 2015; Eroğlu and Bektaş, 2016; Kızılay, 2016). In addition, this is a positive development for a country in which STEM studies have just begun. However, it is insufficient. The teachers participated in the study stated that the effect of the STEM education on the students is quite drastic. It was identified that its impact to the course and the teacher, which were other dimensions of the questionnaire, was less. The finding that participants considered that the STEM education has a low effect on the teacher and the course may be due to the fact that the education programs, the pre-service trainings and the trainings provided in the service are not STEM-based. The teachers may consider that it would not be possible to form a contribution to the colleagues and therefore positive perception or attitude especially without integrating STEM into the curriculum. Yaşar et al. (2006) emphasized the importance of assessing perceptions and preferences of the pre-service or in-service teachers related to engineering design before developing a curriculum for STEM. It was observed that the STEM awareness of the school administrators is quite high. .It is identified that of the administrators, students would embody information, become productive, as well as it would provide curiosity and motivation, contribute to cognitive, emotional and psychomotor skills of students and expand horizon of students. A small proportion of them stated that they have no idea and there would be no contribution. This finding is in accordance with the answers given by the teachers and reinforces the view that STEM education would contribute further to the students. Numerous studies supporting this finding are available in the literature (Capraro et al., 2013; Chang et al., 2015). The majority of the administrators stated that the implementation of STEM is feasible and its effect on courses is available and some administrators stated that it is not. When asked reasons failure to implement STEM activities in the class, the administrators stated that curriculums are not relevant for STEM education and infrastructure is insufficient and teachers are not equipped well for STEM education. The views of administrators, that is "programs appropriate to STEM should be developed to teach STEM and teachers should be motivated for this STEM integrated education program" are consistent with the finding of Custer and Daugherty (2009) indicating it is necessary for program developers to have a comprehensive and flexible structure that meets the school and student needs that will contribute to the professional development of teachers in order for the more effective integration of STEM education into programs. In particular, it must be comprehensive covering all of the science teachers (Bayer, 2009). In the study of Penuel et al. (2007) conducted with the 454 science teachers, it was identified that those provided with equipment and technology support contributed significantly in the integration of the program and changes in science teaching practices. In the literature, the importance of school administrators is emphasized especially in the realization of STEM programs in schools, principals should be more concerned with STEM education and opportunities should be given them in this regard (Brown et al., 2011; Al Salami et al., 2017). In addition, the statement of "teachers should have a serious in-service training, should be informed what to do and how to do it, should be equipped with new generation information and technology" is an opinion that teachers have a lack of equipment and this would be one of the reasons underlying the low mean score of the effect of STEM education on teachers. Similarly, the majority of the administrators stated that teachers were not equipped well to teach STEM and a small proportion of them stated that there would not be an impact of STEM on teachers. The administrators supported their opinions with expressions such as teachers should take in-service training, train themselves in the field of STEM in their schools, teachers do not have enough knowledge about STEM and teachers are insufficient in preparing STEM training-focused course plans. Teachers are important factors in determining quality as well as achievement of STEM integration program. Therefore, it is important for them to acquire knowledge and skills especially the STEM-specific methods of teaching such as project-based learning (Khairani, 2017). These opinions support the outcomes of the study of Kurt and Pehlivan (2013) which indicate that teachers and teacher candidates are insufficient in pedagogical content knowledge and there is a lack of practice. El-Deghaidy et al. (2017) stated in their study, in which views of secondary school science teachers about STEM education and its interdisciplinary structure were examined, that teachers are not prepared for the STEM practices and it is necessary to form a professional development model established by the university-industry cooperation based on the school. It is especially important that teachers of STEM field should master pedagogical knowledge, branches, technological, pedagogical field (National Research Council [NRC], 2012). It is also possible to encounter studies emphasizing the need to increase positive views of teachers about STEM-based course activities in the international literature (Bracey and Brooks, 2013; Pinnell et al., 2013; Akgündüz et al., 2015; Akaygün and Aslan-Tutak, 2016; Çınar et al., 2016; Aslan-Tutak et al., 2017; Shernof et al., 2017). In the study, opinions of teachers about STEM education were examined and no significant relation was identified in terms of gender variable. This result is also in accordance with some studies (Karakaya and Avgın, 2016; Yenilmez and Balbağ, 2016). Furthermore, no significance was observed between the views of teachers with science, mathematics and information technologies and their branches. This finding is consistent with the result of Çevik et al. (2017) indicating STEM interests of STEM field teachers did not differ by their branches. Statement of some of deputy managers as "programs should be developed in accordance with this integrated educational trend to teach STEM education 
and new generation teachers should be adapt to this STEM education" and statement of some of managers as "it is imperative that the Ministry of National Education immediately integrates the STEM education into the education system, in which the curriculums were already rearranged. This is because Turkey has to do this to reach the level of contingent civilizations" is an issue that was emphasized by the majority of administrators and this was supported by the studies carried out in the literature. For instance, countries with high success in international exams are known to have STEM curriculums that developed with a strong disciplinary knowledge focusing on 21 st century skills such as inquiry processes, problem solving, critical thinking and innovation. (Marginson et al., 2013; English and Gainsburg, 2016). Today, the need to develop general skills, in-depth conceptual understanding and interdisciplinary links is most important (English, 2016). The integrated STEM that was emphasized by the administrators participating in the research is unfortunately insufficient in Turkey. "Integration of STEM fields "where many studies abroad are being undertaken and government policies are being developed in order to raise the labor force is not yet common in Turkey. In this regard, education policies and programs need to be improved in the scope of entrepreneurship (STEM + E), art/design (STEM-Art, STEAM) and computing (STEMComputing, STEM + C) considering the needs of the country (Akgündüz and Ertepınar, 2015). In the primary and secondary school curriculums modernized in 2017, STEM education under the title of "applied science" was included only in the science course which is among science, mathematics and information technologies curriculums with STEM fields (M.N.E., 2017). This is an indication that Turkey would be insufficient to gain momentum in STEM awareness, interest, attitudes and skills. Considering teachers, who are the practitioners of the program, have an important role in educating adequate individuals by the needs of the time, educators should be qualified in STEM education in educational reform movements (Erdoğan and Çiftçi, 2017). For this reason, it is necessary to plan in accordance with STEM education and teachers and teacher candidates with necessary field knowledge and pedagogical equipment should be supported and essential resource and materials should be provided (Çorlu et al., 2014; Altan et al., 2016). However, there are limited studies indicating in detail the curriculum or program carried out including the quality of the current integration with STEM education (Honey et al., 2014). Nevertheless, educators, politicians, trade and industry organizations underline the urgency of developing STEM skills to overcome current and future social and economic challenges (Marginson et al., 2013; Caprile et al., 2015; Prinsley and Baranyai, 2015). The necessity of becoming almost universally engaged with the STEM education in shaping of innovation and progressing is confronted in many reports. Besides taking the views of secondary school teachers and administrators about STEM education, taking the views of students and parents would be more effective in achieving a holistic opinion. In order to identify the STEM view of Turkey, longitudinal studies can be carried out with more sampling groups. The opinions of a sample group using mixed methods would also contribute to the literature. The gathering of views on STEM education would be more important as practices related to STEM education, developed STEM-based curriculums and schools increase in Turkey. Especially it would be beneficial to take their views after long-term STEM applications in measuring their attitudes, interest and awareness. Apart from the formal education, spreading informally, conducting interviews about STEM would contribute greatly in the field with the increase of STEM citizenship or STEM literacy level.

\section{References}

Akaygün, S. and F. Aslan-Tutak, 2016. STEM images revealing STEM conceptions of pre-service chemistry and mathematics teachers. International Journal of Education in Mathematics, Science and Technology, 4(1): 56-71. View at Google Scholar | View at Publisher

Akgündüz, D. and H. Ertepınar, 2015. A report on STEM education in Turkey: A provisional agenda or a necessity? İstanbul: Scala Basım Yayım Tan.San. ve Tic.Ltd.Şti.

Akgündüz, D.H., M.A. Ertepınar, Ger, S.A. Kaplan and Z. Türk, 2015. The report of STEM education workshop: An assessment on STEM education in Turkey. İstanbul: İstanbul Aydın University STEM Center and Education of Faculty.

Al Salami, M.K., C.J. Makela and M.A. de Miranda, 2017. Assessing changes in teachers' attitudes toward interdisciplinary STEM teaching. International Journal of Technology and Design Education, 27(1): 63-88. View at Google Scholar |View at Publisher

Altan, E.B., H. Yamak and E.B. Kırıkkaya, 2016. A proposal of the STEM education for teacher training: Design based science education. Trakya University Education Faculty Magazine, 6(2): 212-232. View at Google Scholar

Alumbaugh, K.M., 2015. The perceptions of elementary STEM schools in missouri. PhD Thesis, Education Faculty of Lindenwood University.

Aslan-Tutak, F., S. Akaygun and S. Tezsezen, 2017. Collaboratively learning to teach stem: Change in participating pre-service teachers' awareness of STEM. Hacettepe University Education Faculty Magazine, 32(4): 794-816. View at Google Scholar $\mid$ View at Publisher

Baxter, P. and S. Jack, 2008. Qualitative case study methodology: Study design and implementation for novice researchers. Qualitative Report, 13(4): 544-559. View at Google Scholar

Bayer, J.A., 2009. Perceptions of science, mathematics, and technology education teachers on implementing an interdisciplinary curriculum at Blaine Senior High. (Thesis). University of Wisconsin- Stout, Menomonie WI.

Bracey, G. and M. Brooks, 2013. Teachers'n training: Building formal STEM teaching efficacy through informal science teaching experience. ASQ Advancing the STEM Agenda Conference, Grand Valley State University, Michigan.

Brown, R., J. Brown, K. Reardon and C. Merrill, 2011. Understanding STEM: Current perceptions. Technology and Engineering Teacher, 70(6): 5-9. View at Google Scholar

Büyüköztürk, Ş., 2009. Data analysis handbook for social sciences-manual of data analysis for social sciences. Ankara: Pegem Akademi Publishing, Ankara.

Büyüköztürk, Ş., E. Kılıç-Çakmak, Ö.E. Akgün, E. Karadeniz and F. Demirel, 2012. Scientific research methods-scientific research methods. Ankara: Pegem A Publishing.

Capraro, R.M., M.M. Capraro and J.R. Morgan, 2013. STEM project-based learning an integrated science, technology, engineering, and mathematics (STEM) approach. 2nd Edn., Rotterdam: Sense Publishers.

Caprile, M., R. Palmen, P. Sanz and G. Dente, 2015. Encouraging STEM studies for the labour market. Directorate-General for Internal Policies: European Parliament.

Çetin, A. and N. Balta, 2017. Pre-service science teachers views on stem materials and STEM competition in instructional technologies and material development course. European Journal of Educational Research, 6(3): 279-288. View at Google Scholar | View at Publisher

Çevik, M., D.A. Şanlıtürk and A. Yağcl, 2017. Evaluation of STEM (Science - Technology - Engineering - Mathematics) awareness of secondary school teachers with various variables. Sakarya University Journal of Education, 7(3): 584-599.

Chang, S.H., A.C. Ku, L.C. Yu, T.C. Wu and B.C. Kuo, 2015. A science, technology, engineering and mathematics course with compute rassisted remedial learning system support for vocational high school students. Journal of Baltic Science Education, 14(5): 641-654. View at Google Scholar

Çınar, S., N. Pırasa, N. Uzun and S. Erenler, 2016. The effect of STEM education on pre-service science teachers' perception of interdisciplinary education. Journal of Turkish Science Education, 13(Special Issue): 118-142. View at Google Scholar 
Çorlu, M.S., R.M. Capraro and M.M. Capraro, 2014. Introducing STEM education: Implications for educating our teachers for the age of innovation. Eğitim ve Bilim, 39(171): 74-85. View at Google Scholar

Custer, R.L. and J.L. Daugherty, 2009. The nature and status of STEM professional development: Effective practices for secondary level engineering education. Research in engineering and technology education. Logan, UT: National Center for Engineering and Technology Education. Department of Engineering Education, Utah State University.

DeBiase, K., 2016. Teacher preparation in science, technology, engineering, and mathematics instruction. Dissertation Collection, Department of Educational Leadership, Long Beach California State University.

Dicicco-Bloom, B. and B. Crabtree, 2006. The qualitative research interview. Medical Education, 40(4): 314-32 1. View at Google Scholar

Ekiz, D., 2004. Investigation of the education world by quality research paradigm: Natural or structure. Turkish Educational Sciences, 2(4): 415-439.

El-Deghaidy, H., N. Mansour, M. Alzaghibi and K. Alhammad, 2017. Context of STEM integration in schools: Views from in-service science teachers. EURASIA Journal of Mathematics, Science \& Technology Education, 13(6): 2459-2484. View at Google Scholar | View at Publisher

English, L.D., 2016. STEM education K-12: Perspectives on integration. International Journal of STEM Education, 3(3): 1-11. View at Google Scholar $\mid$ View at Publisher

English, L.D. and J. Gainsburg, 2016. Problem solving in a 21 st-century mathematics curriculum. In L. D. English \& D. Kirshner (Eds.), Handbook of international research in mathematics education. 3rd Edn., New York: Taylor \& Francis. pp: 313-335.

Erdoğan, I. and A. Çiftçi, 2017. Investigating the views of pre-service science teachers on stem education practices. International Journal of Environmental and Science Education, 12(5): 1055-1065. View at Google Scholar

Eroğlu, S. and O. Bektaş, 2016. Ideas of science teachers took STEM education about STEM based activities. Journal of Qualitative Research in Education, 4(3): 43-67. View at Google Scholar

Field, A., 2005. Discovering statistics using SPSS. 2nd Edn., Thousand Oaks, CA: Sage Publications, Inc.

Guskey, T.R., 2002. Does it make a difference? Evaluating professional development. Educational Leadership, 59(6): 45-51. View at Google Scholar

Honey, M., G. Pearson and A. Schweingruber, 2014. STEM integration in K-12 education: Status, prospects, and an agenda for research. Washington: National Academies Press.

Karakaya, F. and S.S. Avgın, 2016. Effect of demographic features to middle school students' attitude towards STEM. Journal of Human Sciences, 13(3): 4188-4198. View at Google Scholar | View at Publisher

Karasar, N., 2007. Scientific research method. Ankara: Nobel Publication Distribution.

Khairani, A.Z., 2017. Assessing urban and rural teachers' competencies in STEM integrated education in Malaysia. MATEC Web of Conferences, 87 .

Kızılay, E., 2016. Pre-service science teachers' opinions about STEM disciplines and education. Journal of Academic Social Science Studies, 47: 403-417. View at Publisher

Kline, P., 2000. The handbook of psychological testing. 2nd Edn., London and New York: Routledge.

Kristin, L., T.H. Nelson, D. Slavit and R.A. Seidel, 2016. Supporting middle school teachers' implementation of STEM design challenges. School Science and Mathematics, 116(4): 177-188. View at Google Scholar View at Publisher

Kurt, K. and M. Pehlivan, 2013. Integrated programs for science and mathematics: Review of related literature. International Journal of Education in Mathematics, Science and Technology, 1(2): 116-121.

Laboy-Rush, D., 2011. Integrated STEM education through project-based learning. Retrieved from https://www.rondout.k12.ny.us/common/pages/DisplayFile.aspx?itemId=16466975.

M.N.E., 2017. The curriculum of science course. Ankara: Board of Education and Training.

Mack, N., C. Woodsong, K.M. MacQueen, G. Guest and E. Namey, 2005. Qualitative research method: A data collector's field guide. USA: Family Health International.

Marginson, S., R. Tytler, B. Freeman and K. Roberts, 2013. STEM: Country comparisons. Melbourne: Australian Council of Learned Academies.

Miles, B.M. and M.A. Huberman, 1994. Qualitative data analysis. 2nd Edn., Thousand Oaks Ca: Sage Publications. USA.

National Research Council [NRC], 2012. A framework for k-12 science education: Practices, crosscutting concepts, and core ideas. Washington DC: The National Academic Press.

Öner, A.T. and R.M. Capraro, 2016. Is STEM academy designation synonymous with higher student achievement? Education and Science, 41(185): 1-17. View at Google Scholar

Oparaocha, D.O., 2017. Urban high school students in STEM programs: An explanatory case study. Ph.D. Dissertation, Capella University.

Pallant, J., 2007. SPSS survival manual: A step-by-step guide to data analysis using SPSS for windows. Philadelphia, PA: Open University Press.

Patton, M.Q., 2014. Qualitative research and evaluation methods. M. Whole and S.B. Iron, Trans. Ankara: Pegem Academy Publications.

Penuel, W.R., B.J. Fishman, R. Yamaguchi and L.P. Gallagher, 2007. What makes professional development effective? Strategies that foster curriculum implementation. American Educational Research Journal, 44(4): 92 1-958. View at Google Scholar $\mid$ View at Publisher

Pinnell, M., J. Rowley, S. Preiss, S. Franco, R. Blust and R. Beach, 2013. Bridging the gap between engineering design and PK-12 curriculum development through the use of the STEM education quality framework. Journal of STEM Education, 14(4): 28-35. View at Google Scholar

Prinsley, R. and K. Baranyai, 2015. STEM skills in the workforce: What do employers want? Occasional Papers Series Office of the Chief Scientist $(9)$

Shernof, D.J., S. Sinha, D.M. Bressler and L. Ginsburg, 2017. Assessing teacher education and professional development needs for the implementation of integrated approaches to STEM education. International Journal of STEM Education, 4(1): 2-16. View at Google Scholar $\mid$ View at Publisher

Siew, M.N., N. Amir and C.L. Chong, 2015. The perceptions of pre-service and in-service teachers regarding a project-based STEM approach to teaching science. Springer Plus, 4(1): 1-20. View at Google Scholar | View at Publisher

Spanneut, G., 2010. Professional learning communities, principals, and collegial conversations. Kappa Delta Pi Record, 46(3): 100-103. View at Google Scholar | View at Publisher

Tabachnick, B.G. and L.S. Fidell, 2015. Using multivariate statistics-Using multivariate statistics. M. Baloğlu, Trans. Ed. 6th Edn., Ankara: Nobel Publishing House.

Tamara, A.F.O., B. Karen, F. Frederick and J. Phillip, 2016. Experiences and perceptions of STEM subjects, careers, and engagement in stem activities among middle school students in the maritime provinces. Canadian Journal of Science, Mathematics and Technology Education, 16(2): 153-168. View at Google Scholar | View at Publisher

Tavşancıl, E., 2005. Measuring attitudes and SPSS data analysis with [Measuring attitudes and data analysis with SPSS]. Ankara: Nobel.

Yaşar, S., D. Baker, S. Robinson-Kurpius, S. Krause and C. Roberts, 2006. Development of a survey to assess K-12 teachers' perceptions of engineers and familiarity with teaching design, engineering, and Technology. Journal of Engineering Education, 95(3): $205-216$. View at Google Scholar | View at Publisher

Yenilmez, K. and M.Z. Balbă̆, 2016. The STEM attitudes of prospective science and middle school mathematics teachers. Journal of Research in Education and Teaching, 5(4): 301-307.

Yıldırım, A. and H. Şimşek, 2005. Qualitative research methods in social sciences qualitative research methods in the social sciences. 5th Edn., Ankara: Seçkin Publishing.

Yin, R.K., 2009. Case study research: Design and methods. Thousand Oaks: Sage. 